\title{
EFFECT OF HIBISCUS SABDARIFFA ON REARING PERFORMANCE OF SILKWORM , BOMBYX MORI L. Nagat Hamed Soliman
}

Plant Protection Department, Faculty of Agriculture, El Fayoum University, Egypt.

\begin{abstract}
Effect of Hibiscus sabdariffa as food additives on rearing performance of silkworm, Bombyx mori L. was studied. Dried flowers of $H$. sabdariffa were crushed and soaked in distilled water to prepare different concentrations $(20,40,60,80$ and $100 \mathrm{mg} / \mathrm{ml}$.). The obtained results showed that, the concentration $60 \mathrm{mg} / \mathrm{ml}$. of $H$. sabdariffa occupied the first category. Where effective rate of rearing recorded $84.00 \%$ compared to $76.00 \%$ in control, total haemolymph protein $\mathrm{mg} / \mathrm{ml}$. recorded $70.54 \mathrm{mg} / \mathrm{ml}$. compared to $64.52 \mathrm{mg} / \mathrm{ml}$. in control and number of eggs / female recorded 284.00 compared to 262.00 in control. Cocoon indices were $1.165 \mathrm{~g}, 0.229 \mathrm{~g}$ and $19.66 \%$ for cocoon, cocoon shell weights and cocoon shell ratio comparing to $1.067 \mathrm{~g}$, $0.169 \mathrm{~g}$ and $17.71 \%$ for the control, respectively.
\end{abstract}

\section{INTRODUCTION}

The mulberry silkworm, Bombyx mori L is monophagous, feeding only on mulberry leaves, there are about 1000 varieties of silkworm (Barnet, 1963), among them bivoltine and multivoltine races are used for rearing in our country (Krishnaswami et al., 1973). Plant derived medicines have been part of our traditional health care in most parts of the world and there has now been an increasing interest in using plants as the sources of agents to fight microbial diseases (Sandhya et al.,2006). Hibiscus sabdariffa is very important medicinal plant, the chemical analysis of calyx revealed that, it contained protein, fat, carbohydrate, fiber, calcium, phosphorus, iron, vitamin A and ascorbic acid (Adegunloye et al.,1996). Various antioxidant constituents are found in the calyx and flower petals of roselle, such as anthocyanins, quercetin, ascorbic acid, ß-sitosteroid glycoside and protocatechuic acid (Salah et al.,2002). The present study has been planned to determine the effect of $H$. sabdariffa as food additives on rearing performance of silkworm, B. mori, L.

\section{MATERIALS AND METHODS}

During spring season of 2015 at Plant Protection Dept. Fac. of Agric., El Fayoum Univ. The effect of Hibiscus sabdariffa on rearing performance of silkworm, Bombyx mori L., was studied. Egg box of silkworm, B. mori L. (Egyptian hybrid) was obtained from the Seric. Res. Dept., Plant Protec. Res. Inst, Agric. Res. Center. Dokki, Giza. Dried flowers of $H$. sabdariffa was obtained from pharmacy and were crushed and soaked in distilled water to prepare different concentrations. Larvae of B. mori L. were reared on fresh mulberry leaves (Morus alba var. indicia)

Fayoum J. Agric. Res. \& Dev., Vol. 32, No.1, January, 2018 
grown in the farm of faculty of Agriculture at Fayoum (at Dar El Ramd region ) under laboratory conditions $\left(28 \pm 2^{\circ} \mathrm{C}, 70 \pm 5 \% \mathrm{RH}\right)$. At the beginning of the $5^{\text {th }}$ instar, larvae were divided into five groups (in addition to the control). Each group contained five replicates (each of twenty larvae). Each replicate was reared in carton tray $(30 \times 15 \times 4 \mathrm{~cm})$.

Larvae of $B$. mori L. were fed on mulberry leaves sprayed with each concentration of $(20,40,60,80$ and $100 \mathrm{mg} / \mathrm{ml}$.) of $H$. sabdariffa daily during the $5^{\text {th }}$ instar after drying on ambient air temperature for one minute. While the control was fed on mulberry leaves sprayed with distilled water. Tested parameters (Effective rate of rearing, number of eggs / female, cocoon $\&$ cocoon shell weights and cocoon shell ratio) were recorded. Total protein of haemolymph was analyzed according to Bradford, 1976. Data was analyzed by ANOVA through statistical package for social science (SPSS) according to Berkowitz and Allaway, 1998 to find out the significance between treated and control. Means were separated by (L.S.D at $0.05 \%$ ).

\section{RESULTS AND DISCUSSION}

\section{Effective rate of rearing:}

Data presented in Table (I) showed a significant change in the treated groups with $H$. sabdariffa when compared to control ones for the effective rate of rearing. Where the best result $(84.00 \%)$ has been obtained by using $60 \mathrm{mg} / \mathrm{ml}$ concentration of $H$. sabdariffa. This increase might be due to the effect of gossypetin component of $H$. sabdariffa as anti-bacterial which might decrease the mortality percentages as reported by Mounnissamy et al., 2002. The obtained results are in general agreement with the findings of many authors whom found that, effective rate of rearing of $B$. mori larvae was improved when using mulberry leaves treated with Parthenium hysterophorus, Tridax procumbens and Tribulus terrestris, (Murugesh and Bhaskar, 2007), mulberry leaves treated with aqueous extract of Phyllanthus niruri, (Kumari et al., 2010).

\section{Total haemolymph protein:}

According to data in Table (I) Total haemolymph protein was significantly increased in the treated groups with $H$. sabdariffa when compared to control. It was $70.54 \mathrm{mg} / \mathrm{ml}$ when larvae treated with $60 \mathrm{mg} / \mathrm{ml}$ of $H$. sabdariffa comparing to $66.82 \mathrm{mg} / \mathrm{ml}$ in control. This increase may be due to the effect of $H$. sabdariffa antioxidant (Guyton \& Kensler, 1993 and Crawford et al., 1998). Similar results was obtained by Raju et al., 2012 when using mulberry leaves treated with turmeric on B. mori larvae.

Number of eggs / female:

Number of eggs / female was significantly increased in the treated groups of $H$. sabdariffa when compared to control as presented in Table (I). The obtained results agreement with Shubha $\boldsymbol{e t}$ al., 2006 when using mulberry leaves treated with aqueous extract of Psoralea corylifolia,

Fayoum J. Agric. Res. \& Dev., Vol. 32, No.1, January, 2018 
EFFECT OF HIBISCUS SABDARIFFA ON REARING

Phyllanthus niruri, Tribulus terrestris, Withania somnifera and Adathoda vasica and Sumathi, 2008 when using mulberry leaves treated with aqueous extract of Lantana camera and Ocimum sanctum on B. mori larvae.

TABLE(I):Effect of feeding Bombyx mori L. larvae on mulberry leaves treated with different concentrations of Hibiscus sabdariffa on some parameters.

\begin{tabular}{|c|c|c|c|}
\hline $\begin{array}{c}\text { Concentrations of } \\
\text { H. sabdariffa by } \\
\text { mg/ml of water. }\end{array}$ & $\begin{array}{c}\text { Effective rate of } \\
\text { rearing(\%). }\end{array}$ & $\begin{array}{c}\text { Total haemolymph } \\
\text { protein }(\mathbf{m g} / \mathbf{m l} .) .\end{array}$ & $\begin{array}{c}\text { Number of eggs / } \\
\text { female. }\end{array}$ \\
\hline $\mathbf{2 0}$ & $79.00 \pm 1.5802 \mathrm{~b}$ & $68.54 \pm 2.478 \mathrm{ab}$ & $273.54 \pm 11.5803 \mathrm{ab}$ \\
\hline $\mathbf{4 0}$ & $81.00 \pm 2.5538 \mathrm{ab}$ & $68.90 \pm 1.147 \mathrm{ab}$ & $264.89 \pm 9.5008 \mathrm{ab}$ \\
\hline $\mathbf{6 0}$ & $84.00 \pm 2.9455 \mathrm{a}$ & $70.54 \pm 1.851 \mathrm{a}$ & $284.00 \pm 8.1455 \mathrm{a}$ \\
\hline $\mathbf{8 0}$ & $78.00 \pm 3.5971 \mathrm{~b}$ & $67.98 \pm 2.488 \mathrm{ab}$ & $272.03 \pm 8.5973 \mathrm{ab}$ \\
\hline $\mathbf{1 0 0}$ & $78.00 \pm 2.2626 \mathrm{~b}$ & $67.69 \pm 1.408 \mathrm{ab}$ & $260.00 \pm 12.2626 \mathrm{~b}$ \\
\hline Control & $79.00 \pm 2.4221 \mathrm{~b}$ & $66.82 \pm 2.335 \mathrm{~b}$ & $262.00 \pm 10.4221 \mathrm{ab}$ \\
\hline F test & $*$ & $*$ & $*$ \\
\hline LSD at $\mathbf{0 . 0 5 \%}$ & 3.445 & 3.009 & 23.65 \\
\hline
\end{tabular}

\section{Cocoon weights, cocoon shell weights and cocoon shell ratio:}

Data in Table (II) represent cocoon, cocoon shell weights means and cocoon shell ratio which were increased especially when larvae treated with $60 \mathrm{mg} / \mathrm{ml}$ of $H$. sabdariffa. Where the obtained results were $1.165 \mathrm{~g}$, $0.229 \mathrm{~g}$ and $19.66 \%$ for cocoon, cocoon shell weights and cocoon shell ratio comparing to $1.067 \mathrm{~g}, 0.169 \mathrm{~g}$ and $17.71 \%$ for the control, respectively. This increasing may be due to the effect of $H$. sabdariffa which increased total haemolymph protein. The obtained results are in general agreement with the findings of many authors whom found that, cocoon, cocoon shell weights and cocoon shell ratio of $B$. mori were increased when using mulberry leaves treated with aqueous extract of Murraya koenigii, (Ganesan and Isaiarasu, 2007), with aqueous extract of Lantana camera and Ocimum sanctum, (Sumathi, 2008) and with aqueous extract of Andrographis panciculata and Plumbago zeylanica, (Takhlique, 2011). 
TABLE (II):Effect of feeding Bombyx mori L. larvae on mulberry leaves treated with different concentrations of Hibiscus sabdariffa on cocoon parameters.

\begin{tabular}{|c|c|c|c|}
\hline $\begin{array}{c}\text { Concentrations of } \boldsymbol{H} . \\
\text { sabdariffa by mg/ml of } \\
\text { water. }\end{array}$ & $\begin{array}{c}\text { Cocoon weights } \\
(\mathbf{g}) .\end{array}$ & $\begin{array}{c}\text { Cocoon shell } \\
\text { weights }(\mathbf{g}) .\end{array}$ & $\begin{array}{c}\text { Cocoon shell } \\
\text { ratio }(\boldsymbol{\%}) .\end{array}$ \\
\hline $\mathbf{2 0}$ & $1.105 \pm 0.003 \mathrm{ab}$ & $0.189 \pm 0.005$ & $17.10 \pm 1.007$ \\
\hline $\mathbf{4 0}$ & $1.082 \pm 0.022 \mathrm{bc}$ & $0.205 \pm 0.026$ & $18.94 \pm 1.306$ \\
\hline $\mathbf{6 0}$ & $1.165 \pm 0.013 \mathrm{a}$ & $0.229 \pm 0.017$ & $19.66 \pm 0.0320$ \\
\hline $\mathbf{8 0}$ & $1.026 \pm 0.005 \mathrm{bc}$ & $0.165 \pm 0.007 \mathrm{~b}$ & $16.08 \pm 0.1141$ \\
\hline $\mathbf{1 0 0}$ & $1.011 \pm 0.003 \mathrm{c}$ & $0.167 \pm 0.009 \mathrm{~b}$ & $16.51 \pm 0.1833$ \\
\hline Control & $1.067 \pm 0.012 \mathrm{bc}$ & $0.179 \pm 0.003 \mathrm{~b}$ & $17.71 \pm 0.4008$ \\
\hline F test & $*$ & - & - \\
\hline LSD at $\mathbf{0 . 0 5 \%}$ & 0.082 & - & - \\
\hline
\end{tabular}

\section{REFERENCES}

Adegunloye, B. J.; Omoniyi, J. O. and Ajabonna O.P.(1996). Mechanism of blood pressure lowering effects of the calyx extract of Hibiscus sabdariffa in rats. Journal of Science, 5: 235-238.

Barnet, L. (1963). The wonders of life and earth parentic and hall . Landon, pp: 48.

Berkowitz, D. and Allaway, A. (1998). Statistical package for social sciences (SPSS), Version 7.5 for Windows NT/Windows 95:130-132.

Bradford, M. M. (1976). A rapid and sensitive method for quantities of microgram quantities of protein-dye binding. Anal. Biochemical,72: 248-254.

Crawford, R. S.; Chait, A. ; Malvis, D. and Peter, M. (1998). Physicochemical characteristics of roselle (Hibiscus sabdariffa). Nutritional Food Science, 32: 68-73.

Ganesan, R. and Isaiarasu, G. (2007). Effect of the curry leaf extract on growth and cocoon characteristics of Bombyx mori L. Journal of Ecotoxicology \& Environmental Monitoring. 17(3): 281-284.

Guyton, K. Z. and Kensler, T. W. (1993).The effect of sour tea (Hibiscus sabdariffa) on essential hypertension. Ethnopharmacology, 65:231-236.

Krishnaswami, S. ; Vijayraghavan, S. and Krishnaswami, S. (1973). Studies on fortification of mulberry leaves for feeding silkworm. Int. J. Seri., 11(1):68 -72.

Kumari, S. S.; Bhaskar, R. N.; Peter, A.; Narayanaswamy, K. C. and Fatima S. (2010). Deterioration of rearing parameters of $\mathrm{PMxCSR}_{2}$ due to Aspergillus infection. Bulletin of Indian Academy of Sericulture, 14(2): 7-12.

Fayoum J. Agric. Res. \& Dev., Vol. 32, No.1, January, 2018 
EFFECT OF HIBISCUS SABDARIFFA ON REARING 49

Mounnissamy, V. M.; Kavimani, S. and Gunasegaran, R. (2002). Antibacterial activity of gossypetin isolated from Hibiscus sabdariffa. The Antiseptic, 99(3):81-82.

Murugesh, K. A. and Bhaskar, R. N. (2007). Efficacy of botanicals on larval growth of silkworm, Bombyx mori L. and its impact on silk productivity. Bulletin of Indian Academy of Sericulture,1(1): 11-15.

Raju, H. A. ; Mamatha, D. M. ; Rao, M. R. and Kanji, V.K. (2012). Impact of turmeric on the protein and lipid metabolic profiles of silkworm, Bombyx mori L. and cocoon production. Current Biotica, 6(2): 208-226.

Salah, A. M.; Gathumbi, J. and Verling, W. (2002). Inhibition of Intestinal motility by methanolic extracts of Hibiscus sabdariffa in rats'. Phytochemical Resources, 16:283-285.

Sandhya, B. ; Thomas, S.; Isabel, W. and Shenbagarathai, R. (2006). Ethno medicinal plants used by the Valaian community of Piranmalai hille, India. African Journal of Traditional, Complementary and Alternative Medicines, 3 (1):101-114.

Shubha, K.; Bhaskar, R. and Chikkalingaiah, N. (2006). Role of medicinal botanical extracts on grainage parameters of PM $\mathrm{x}$ $\mathrm{CSR}_{2}$. Environment and Ecology, 24S: Special 3: 662-664.

Sumathi, S. (2008). Supplementation of plant extracts on economic parameters of silkworm Bombyx mori L. Journal of Ecotoxicology \& Environmental Monitoring, 18(5) : 445-450.

Takhlique, M. (2011). Medicinal plant extracts a great determinant to economic potency of silkworm: Bombyx mori L. Journal of Entomological Research, 35(3): 231-233.

Fayoum J. Agric. Res. \& Dev., Vol. 32, No.1, January, 2018 


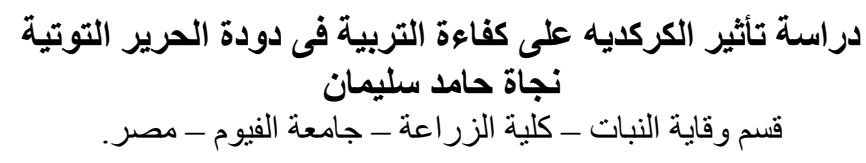

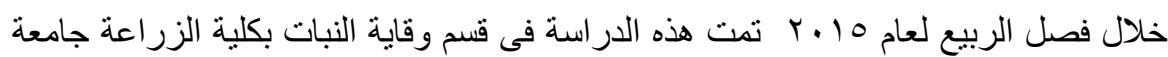

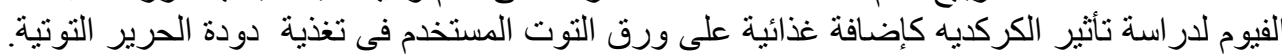

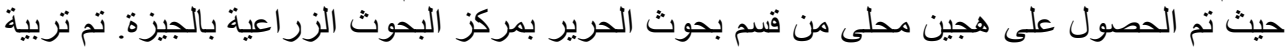

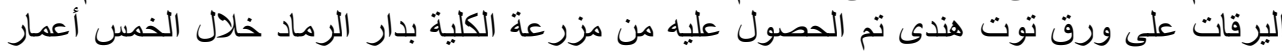

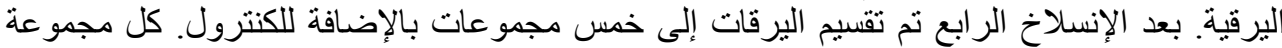

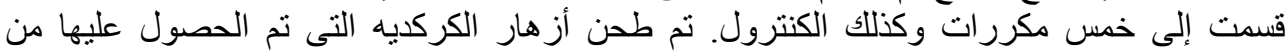

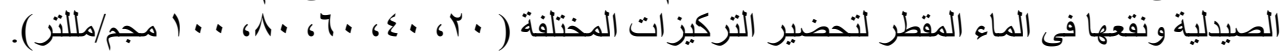

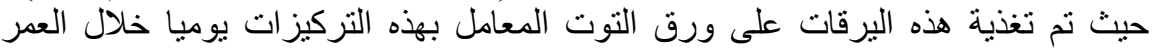

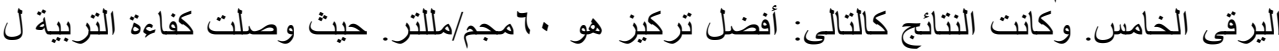

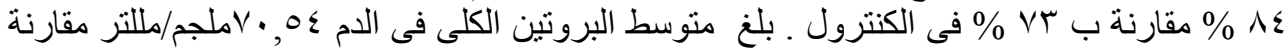

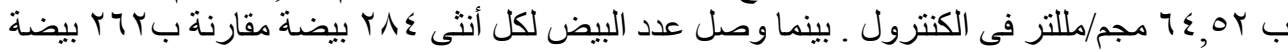

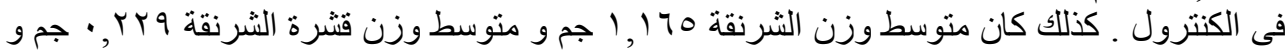

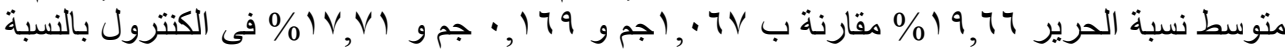
للصفات السابقة على التو الى.

Fayoum J. Agric. Res. \& Dev., Vol. 32, No.1, January, 2018 